\title{
Utopija 1515-2015 Thomas More: Utopija 1515 (prev. Bogdan Gradišnik). Stephen Duncombe: Odprta utopija 2015
}

\author{
Ljubljana: Studia humanitatis, 2014, 191 strani
}

Ko danes, po petstotih letih, beremo Utopijo Thomasa Mora (7. 2. 1478 - 6. 7. 1535), vemo, da gre v sodobnem času spoznanje pred utopijo in ne več utopija pred spoznanjem. Kako torej brati Morovo Utopijo 1515 zdaj, ko utopizem pri mnogih velja domala že za totalitarizem? Morda sveta sploh ne želimo več spreminjati, kajti potopljeni smo $\mathrm{v}$ čisto samozadostno kritiko, ki je sama sebi namen, v stvarnosti nočemo več videti možnosti za drugačnost, ki bi lahko svet in razmere $\mathrm{v}$ njem spreminjala. Kot da bi postutopična, tj. protiutopična naravnanost pomenila razvojno usmeritev, ki vpije: Bolj kot se spreminja, bolj je isto. Večno vračanje enakega v podobi nič več načelo solidarnosti, ampak toleranca in povrhu se vsi v politiki drenjajo okrog sredine.

Zdajšnja doba naj bi po mnenju mnogih končala čas revolucij, dvestoletno obdobje od leta 1789 do 1989. Toda s to dobo nikakor nismo dokončno opravili, kajti mišljenjska struktura, način dojemanja, razmišljanja in vrednotenja, povezan s preteklim dogajanjem, ni povsem za nami in še dolgo ne bo. Mnogi intelektualci so prestrašeni zaradi moči občih idej in njihove volje do moči; pri tem se depolitizirajo in svarijo, da je na začetku morda res enakost in bratstvo, na koncu pa giljotina. Po sesutju socializma boljševiškega izvora smo soočeni $\mathrm{z}$ nemajhno nalogo: aktualno namreč ostaja vprašanje, kako razmišljati o utopiji, upanju, pravičnosti, celo o zgodovini sami in o pojmu napredka, ki je povezan z njo. Tako še posebej po letu 1989 izstopa znana parola o t. i. koncu utopij in o koncu utopične zavesti.

Dela, ki se ukvarjajo z omenjeno temo, razpravljajo o pluralizmu, ta pa poudarja duha razlik v primerjavi s komaj preteklo dobo, ki je izrecno vztrajala pri duhu totalitete in identitete. Vodilno načelo ni več solidarnost, ampak toleranca! Na podlagi "razmoralizirane kulture diferenc" razumljeno bistvo moderne demokracije ni več konsenz, ampak dispenz. Vsaj v prvem trenutku se zdi, kot da v pluralizmu ne bi bilo več mesta tudi za kaj utopičnega. Levičarstvo 21. stoletja kapitalizma ne ogroža in mu vsepovsod celo dopoveduje, naj obstane in vztraja v taki ali drugačni, še tako posredni obliki, in kljub vsem retoričnim kritikam v bistvu kapitalistične interese celo podpira. 
Zdajšnje levičarstvo je s kapitalizmom solidarno, kot táko v obliki kritike pomeni kvečjemu salonsko in medijsko levičarstvo, skratka, malo ironično rečeno, na levo se da kritizirati, če ima človek za seboj desno publiko - ki si jo sproti ustvarja -, s trajno rezerviranimi tapeciranimi sedeži, siromaštvo delavcev pa je že dolgo amputirana kategorija leve tradicije, ki izraza proletariat noče več uporabljati.

Kar je bilo pri velikih mojstrih mišljenja intelektualne levice (Sartre, Marcuse) pred samo še nekaj desetletji razpoznavni znak za napredno intelektualčevo držo, namreč univerzalizacija, učinkuje danes že kot nekakšna mora preteklosti. Prizadevanje za univerzalizacijo in iz tega izhajajoča nekdanja politizacija sta bila razčarana do te mere, da po letu 1989 govorimo celo o razčaranem intelektualcu. Za to razčaranost je značilna izrecna depolitizacija, ki je tako očitna, da se zahodni intelektualci zavestno odločajo za t. i. estetizacijo, kajti zdaj popularna kultura razlik, duh diference (toleranca) in ne več včerajšnje totalitete, identitete (ideja organizirane solidarnosti), »raztaplja politiko v estetiko« (Richard Saage: Das Ende der politischen Utopie?, Suhrkamp, Frankfurt na Majni 1990, 10).

Estetizacija intelektualcev kot tipičen pojav časa pomeni tole: »Na mesto socialno angažiranega stopa estetsko dezangažirana subjektivnost. Vse postaja interpretacija, zapletena v zgodbe brez konca« (Hauke Brunkhorst: Der entzauberte Intellektuelle. Über die neue Beliebigkeit des Denkens, Junius, Hamburg 1990, 82). Etična naravnanost se pri tem povsem izgublja, ni je, pisanje je brez tendence. Meje med toleranco in netoleranco postajajo krhke celo tako zelo, da zaradi nebrzdanega gojenja individualnosti toleranca $\mathrm{v}$ marsičem pomeni nevarno bližino nihilizma, po Sloterdijku cinizma in še bolj panike.

Kaj je bistvo resnice pluralizma? Zanimiv odgovor je tale: »Diferenca je parola, s katero duh časa vse združuje.« Zavreči je treba totalitarni (solidarnostni) um, saj je bil vse preveč hierarhičen, šele »duh diference je duh čiste, nepotvorjene tolerance«, in naš čas potrebuje »transverzalni um« (prav tam). Vendar definicija tega uma ni ravno spodbudna, kajti za imenom transverzalni um se skriva nič drugega kot dobra stara moč razsojanja, moderno okrašen zdravi razum (common sense). Že Heglu je bilo jasno, da je stališče zdravega razuma - kdor se ne strinja z menoj, je proti meni - s humanostjo in solidarnostjo v medčloveških odnosih hudo sprto, in duhu, ki razmišlja na tej ravni, očita, da sploh še ni dojel tega, kaj je njegovo pravo bistvo.

Sodobni nemški filozof Peter Sloterdijk (roj. 1947), ki se samozavestno označuje za »špilferderberskega egomana«, in je kot tak izzval celo Jürgena Habermasa (roj. 1929), se ni ustrašil nobene posledice tega, kar je povedal, in nam še vedno pogosto govori po nemški televiziji 3 sat, med drugim tudi o tem, da je klavrno sesutje socializma v vzhodni Evropi celo sam zmagoviti kapitalizem spravilo v zadrego. Zaveda se tudi, da takrat, ko gre za grozljivo nastajanje težkih in neobvladliivih socialnih vprašanj ter za siromašenje 
zelo velikega števila prebivalstva $\mathrm{v}$ deželah nekdanjega socializma, »leži na dlani, da povratek k napakam preteklosti ne bo prinesel njihove rešitve« (Peter Sloterdijk: Srd in čas. Politično-psihološki poskus, Claritas, Ljubljana 2009, 48). Pri tem skuša še na zanimiv način psihološko politično pojasniti, kakšno novo odzivanje se poraja v ljudeh. Po njegovem gre za krepitev posedovalnega nagona, za erotizacijo razmer, kar vse označuje za avanturo postkomunistične duše. Sistem dinamike pohlepa gre »v korist erotiziranja brez meja«: dobiti, prevzeti, imeti, uživati. Ljudi se je lotila denarna mrzlica, obsedeni z retoriko demokracije in neskončnih obljub tržnega gospodarstva začenjajo investirati, najemati posojila za naložbe, ki naj bi se bogato obrestovale.

Ali je možno govoriti o utopiji ekonomije, taki, ki ne bi porajala siromaštva in $\mathrm{v}$ sodobnem svetu armade brezposelnih? Kam naj se obrnemo pred zasvojenostjo s potrošništvom, ki ga določa tržna ekonomija? Peter Sloterdijk v delu Srd in čas, ki je prevedeno tudi v slovenščino, $\mathrm{z}$ Nietzschejevo pomočjo razmišlja $\mathrm{v}$ tej smeri. Bi lahko bila podlaga za njegovo prevrednotenje vrednot tudi kaj iz ekonomije? Georges Bataille je bil po Sloterdijku eden tistih avtorjev, ki so iz Nietzschejevih psiholoških intuicij začeli izvajati »ekonomske posledice. Dojel je, da je Nietzschejev moralni impulz v končni posledici meril na drugačno gospodarstvo« (prav tam, 47). Kakšno torej?

Po Sloterdijku iz človekove duše ne izhaja samo posedovalni nagon, tj. egoizem. Po Platonovi razčlembi je duša trodelna, in sicer najprej iz zgornjega, razumskega dela, ki je podlaga mišljenja, drugi del duše je volitivni, tj. hotenje, pogum in volja, tretji, najnižji, pa pomeni čutenje, nagone, instinkte in poželjivost. Hrabrostni, hotenjski del duše, človekova timotika, pomeni človekov ponos, pogum, srčnost, voljo po uveljavljanju, etiko in celo, kot poudarja Sloterdijk, "zahtevo po pravičnosti, njegov občutek za dostojanstvo in čas, njegovo nejevoljo in njegove bojno-maščevalne energije» (prav tam, 26). Pri tem zelo natančno razloži pomen izraza thymós; slovenimo ga kot srčnost, ki je vir naše potrebe po ponosu, pogumu in dostojanstvu in ki pri posamezniku pomeni tako vir omike kot tudi zelo ustvarjalno in etično dejavno življenjsko načelo.

Antika je lep primer take timotike, ki jo Sloterdijk prenaša na sodobno ekonomijo in je nikakor ne pušča samo v mejah morale. Sprašuje se takole: »A kako naj bi bilo predstavljivo gospodarsko življenje, ki ne bi gradilo na erotičnih impulzih, torej na poželenju, želji po posedovanju, nagonu po (p)osvojitvi, temveč na timotičnih impulzih, kot sta želji po priznanju in samospoštovanju? Kako bi si bilo mogoče predstavljati uvajanje ponosa $\mathrm{v}$ kapitalistično gospodarstvo, ki se v prvi vrsti javno vendarle izreka za primat stremljenja po dobičku, se pravi pohlepa, summa summarum neimenitnega motiva, ki ga tudi njegovi branilci opravičujejo z napotkom, da je podjetniški realist sam zaradi vulgarnosti realnega obsojen na neimenitnost? (prav tam, 47). 
Postkomunistične razmere so takšne, da pomenijo izrazit obrat in odvrnitev od timotike (ponos) v prid in korist erotiziranja (posedovalni nagon) brez meja. Gre za brutalno konverzijo »iz sistemov dinamike srda in ponosa v sisteme dinamike pohlepa«, in to je po Sloterdijku psihopolitična podoba sedanjega sveta v deželah včerajšnjega socializma. V svoji neposredni okolici lahko vsak dan vidimo, kako se je spremenila medčloveškost zaradi pohlepa, ki ga v ljudeh spodbuja kapitalizem. Ta pohlep je v svojem času spoznaval že Thomas More in glasno razmišljal o tem, kakšna naj bi bila utopično urejena družba, kjer nihče ne bi stradal in bi bili vsi zadovoljni, v svetu brez revežev in obrobnežev, ker ima po vseh zakonih narave vsak človek »vso pravico do hrane« (Thomas More: Utopija 1515,73), poudarja More v drugi knjigi svoje Utopije. Ugotavlja tudi, da strah pred pomanjkanjem dela ljudi pogoltne in pohlepne, človek razvije celo napuh, ki ga usmerja zavest, da je zelo prijetno in ugledno vse druge prekašati v prisvajanju dobrin.

Država je skupnost, urejena po določenih načelih, zakonih, ki ljudi povezujejo. Sodobna, pravno urejena država kot skupnost ni več povezovanje na podlagi krvnosorodstvenih razmerij patriarhalne ureditve, ampak je skupnost, ki se povezuje na podlagi zakonov. Te zakone smo si ustvarili mi, ljudje, sami, nihče drug, in te od nas ustvarjene zakone tudi spoštujemo in uresničujemo. Torej: kakšni so ti zakoni, načela povezovanja, bolje: kakšni naj bi bili, da bi se vsi ljudje počutili varne in da bi srečno domovali v svojem kratkem življenju? Država naj ne bo organizirana zarota bogatih in hudobnih sprijencev, ki »dan za dnem znižujejo plačo revežem, še zlasti, ker jih k temu ne spodbujajo le goljufivi nagibi, temveč celo podpora državnih zakonov« (prav tam, 131). Po Moru pa so »hudobni sprijenci« ti, ki »so si v nenasitnem pohlepu med seboj razdelili dobrine, ki bi sicer zadostovale za potrebe vseh« (prav tam, 132), in $\mathrm{v}$ sodobnem duhu zdajšnjosti rečeno odnesli pokradeno $\mathrm{v}$ finančne oaze, recimo na Kajmanske otoke in še kam.

Morova Utopija v prvi knjigi opisuje nenasitno bogatenje teh, ki se ukvarjajo z ovčerejo zaradi proizvodnje volne. "Skoraj vse ovce so se namreč znašle v lasti peščice lastnikov, ki so tako bogati, da jih nič ne sili prodati volne prej, kakor želijo, želijo pa šele takrat, ko jo lahko prodajo za ceno, ki jo želijo« (prav tam, 32). Nenasitni pohlep poraja siromaštvo, ki se mu posmehuje razuzdana potratnost, siromake sili v krajo in bogataši vpijejo, da jih je treba kaznovati. More se sprašuje, kakšna družba je to, ki dela tatove zato, da bi jih kaznovala. Spodbujanje k hudodelstvu vpliva tudi na razumevanje prava oziroma pravice. Tisti, ki je bil kaznovan, celo usmrčen zaradi kraje, je bil kaznovan zato, ker je »užalil pravico in prekršil zakon«. More si upa opozoriti na rek, da je skrajna pravica največja krivica (Summum ius, summa iniuria). More v prvi knjigi Utopije obsoja strogost zakonov, "po katerih je treba izvleči meč«, in opozarja: »Bog je prepovedal ubijati, mi pa mirno ubijamo zaradi tatvine kovanega drobiža« (prav tam, 
CVETKA HEDŽET TOTH / UTOPIJA 1515-2015 THOMAS MORE:

UTOPIJA 1515 (PREV. BOGDAN GRADIŠNIIK). STEPHEN DUNCOMBE: ODPRTA UTOPIJA 2015

34). Torej ne ubijaj, spoštuj življenje, kakor se glasi prva od štirih temeljnih smernic svetovnega etosa (1993), in sodobna demokracija odklanja smrtno kazen.

Pred petstotimi leti je More protestiral proti smrtni kazni za te, ki so kradli, da so preživeli, kajti kazen so jim izrekli ti, ki so jih pred tem sami oropali. In kakšna ironija, da je bil zaradi sporov s takratnim angleškim kraljem Henrikom VIII. sam obsojen na smrt in tudi usmrčen! Že od vsega začetka je kapitalizem ropal, izkoriščal: saj bogastvo nekaterih ne bi bilo vprašljivo, če ne bi zaradi njega nastajala revščina, in vračanje kapitalizma v naš svet to spet potrjuje.

Kopičenje bogastva peščice povzroča po drugi strani množico revežev. Skrivnost tega je v ekonomiji in Morova Utopija je en sam zelo glasen razmislek o tem, kako zgraditi ekonomijo na drugačnih temeljih kot na pohlepu in grabežljivosti. Ta utopična misel nas spremlja še danes, tudi takrat, ko odklanjamo privatizacijo, ker se bojimo izbruha pohlepa, grabežljivosti, izkoriščanja in siromaštva. More opozarja: »Torej je vladarjeva dolžnost, da bolj kakor za svoje užitke skrbi za blagor ljudstva, tako kakor je dolžnost ovčarja, ki želi biti dober pastir, da najprej napase ovce in šele potem nasiti sebe. Kdor misli, da je revščina ljudstva podlaga miru, ga postavlja na laž stvarnost sama« (prav tam, 47). Današnji razvratni tajkuni si kot protipol lumpenproletariatu zaslužijo vzdevek lumpenburžoazija in $\mathrm{z}$ njimi kapitalizem ni nič drugega kot kobiličarski kapitalizem, nenasiten kot kobilice, ki vse požrejo in opustošijo in potem odletijo uničevat naprej.

Državo bi morali voditi sposobni, najvišje funkcije bi bilo nujno »dodeljevati zmožnim« in nikakor ne premožnim, pravica in napredek po Morovi Utopiji nista možna tam, kjer "vsi vse merijo $\mathrm{z}$ denarjem «, in k splošni blaginji vodi ena sama pot - »vpeljava lastninske enakosti«. Na vprašanje, zakaj, More odgovarja s temle: »Kadar namreč vsak človek grabi zase, kolikor more, s to ali ono pravno zahtevo, postane nujno, da si vse razdeli med seboj le peščica ljudi, ne glede na obilico dobrin, medtem ko večini preostane revščina, in navadno je tako, da bi si prvi zaslužili usodo drugih, kajti bogati so pohlepni, nepošteni in nekoristni, revni pa so, nasprotno, skromni, preprosti in z vsakdanjo pridnostjo koristnejši za skupnost kakor zase. Od tod sem trdno prepričan, da ne bo mogoče doseči enakopravne in pravične delitve dobrin oziroma srečno upravljati zadev tega sveta, če se popolnoma ne odpravi zasebno lastništvo. Dokler bo obstajalo, bo večinski, najboljši del človeštva tlačilo mučno, neogibno breme skrbi in revščine» (prav tam, 52-53).

Morova Utopija razmišlja o marsičem, od tega, kako naj bi bila urejena skupnost ljudi tako, da bi bilo za vsakogar vsega zadosti, in podrobnih opisov vsakdanjosti, med drugim, kakšna naj bosta zakon in družina, vse tja do kulture, učenja tujih jezikov in še česa. Preseneča nas, kako utopičnost sega v vse pore življenja. Lahko bi 
bilo drugače kot pa samo je, in nasmehnemo se, ko beremo, da imajo Utopijci prav malo zakonov, »sicer pa jih njihov družbeni red ne potrebuje veliko«, tudi odvetnikov nimajo, »ki bi spretno krmarili pravde in prebrisano razlagali zakone, ker mislijo, da je najprimernejše, če se med pravdo vsakdo zastopa sam« (prav tam, 105).

Utopična zavest ostaja znotraj sveta, čeprav se s svetom ne ujema. Vendar utopija ni isto kot metafizika, ki pomeni praviloma čezsvet, in utopično tudi ni izenačeno s čim onstranskim. Skratka, utopija pomeni protisvet, ki nikdar ne zapušča meja tega sveta. Nekoč, v Morovem času, je bila utopija razumljena bolj prostorsko, celo geografsko, pozneje se je njen pomen prenesel bolj na čas. $S$ tem prejme dragocen pomen, da resnica pomeni ne samo bilost, to-kar-je bilo, ampak prej še-ne, kar sicer še-ni-stvarno, so pa možnosti za-drugo, drugačno od tega, kar-samo-je.

Po tej plati je utopična zavest anticipirajoča zavest, ki opozarja na možnosti, ki so že nakazane, čeprav še ne udejanjene, skratka, utopija ni to, kar-nikdar-ne-bo, tudi ni kraj, ki ga nikjer-ni, ampak je le še-ne-biti. Ni naključje, da je šele z razvito utopično zavestjo zacvetela evropska humanistika, in Morovi Utopiji smo za to njeno poslanstvo zelo hvaležni. Misliti pomeni tudi znati misliti presežno, imeti utopijo je zmožnost spreminjanja stvarnosti - znotraj sveta - po humanih zgledih, imeti utopijo je končno imeti pokončno hojo in iti z dvignjeno glavo skozi življenje. Utopija je zavest pokončne hoje, odprtost za boljše, bolj humano. Pomeni našo rastočo občutljivost in dovzetnost za prepoznavanje potreb ljudi vsega sveta in skrb za ohranjanje svetovne biti in življenja v njej.

Nekaj naj bo povsem jasno: zgodovine ne delajo ideje, nikakor, ampak ljudje s sredstvi, za katera se odločamo. Ravno z izbranimi sredstvi, ki so naša, povsem človeška odločitev, stopamo v zgodovino, ki jo ustvarjamo. Ne samo cilj, namen, ampak še toliko bolj sredstvo za dosego cilja je povsem naša odločitev in vsi se strinjamo, da tisto »dobro«, ki je dosegljivo s terorjem, silo, inkvizicijo, koncentracijskimi taborišči, skratka »dobro«, ki ga usmerjajo krvava sredstva, ne more veljati ne za dobro in ne za etično.

Utopična zavest mora biti strogo vpeta $\mathrm{v}$ zasnutek napredka kot etičnega napredka, ne kot dogma, samo kot usmerjevalec. Vprašanje, ali človek lahko živi brez utopije in upanja na srečo, ni samo sociološko, filozofsko, teološko in metafizično, ampak, in to celo najprej, izrazito antropološko vprašanje, povezano z najtemeljnejšimi človekovimi bivanjskimi razsežnostmi. Ne glede na tragično usodo socializma v 20. stoletju, predvsem glede na njegov trenutni iztek, bolje: konec, utopija nikakor ni samo prestiž nekdanjih ideologov in dežurnih marksistov - teh, ki so dežurali kot oblast pri (pre)polni mizi -, kot utopija tudi ni samo mora preteklosti. 
CVETKA HEDŽET TOTH / UTOPIJA 1515-2015 THOMAS MORE:

UTOPIJA 1515 (PREV. BOGDAN GRADIŠNIIK). STEPHEN DUNCOMBE: ODPRTA UTOPIJA 2015

Utopija in utopično mišljenje bosta vedno povezana s presežnostnim mišljenjem, ki ima pogled usmerjen naprej, zato nam sodobna utopistika (Ernst Bloch) v vrsti svojih del predlaga, da preteklo in staro razumemo iz novega in ne obratno. Skratka, gre za jemanje preteklega iz prihodnjega in nikakor ne za jemanje prihodnjega iz preteklega.

Tema in problematika konca utopije in upanja je navsezadnje mnogo bolj kot $s$ kakšnim dobesednim koncem povezana $\mathrm{z}$ vprašanjem diskontinuitete zgodovinskega razvoja. To, da se misli $z$ utopično vsebino trenutno ne obnavljajo oziroma ne premorejo obnovitvene moči, še ne pomeni izgube spomina na moč utopičnega mišljenja, ki je in ostaja eden od najmočnejših virov trajnega ohranjanja poguma za bivanje. Navsezadnje gre samo za to, da svetu in življenju v njem rečemo da.

Utopija ohranja solidarnostno povezovalno moč med ljudmi, je kot topel tok bivanja, ki posreduje smisel mnogim, sodobna demokracija brez utopične vsebine pa je kot svet iz štirih gumijastih sten, med katerimi lahko kričiš, se mečeš ob tla, delaš, kar hočeš, toda teh štirih sten (sistema) ne boš premaknil, so nepremakljive in nedovzetne za upor in trpljenje ljudi. In tako je pod pretvezo čaščene, samovšečne - čvek - demokracije kritika izpodrinila utopijo. Taka kritika - retorična akrobatika - spominja na celonočni lajež s praznim želodcem v luno, ne da bi od kod priletelo poleno, ki bi želelo utišati razjarjenega. Kako dolgo še, me sprašujejo študenti, ki jim je marsikaj tovrstno »demokratičnega« že presedlo in ki glasno želijo, celo zahtevajo, da kaj utopičnega spet stopi pred spoznanje, ob tem pa odklanjajo demokracijo kot všečno govorjenje.

Enakost je totalitarizem, celo komunajzarstvo, poslušamo pri nas. Tak apokaliptični pohod proti enakosti ni razumljiv, predvsem pa osupne to, da nekateri idejo bratstva znotraj krščanstva imenujejo kar boljševizem antike. Krščanstvu smo za idejo bratstva zelo hvaležni, kajti kakor koli že: zavedamo se, da je ideja enakosti - egalitarizem - prešla iz krščanstva v demokracijo in postala ena njenih najbolj konstitutivnih sestavin. In kako dragoceni prispevki so izšli iz našega krščanskega socializma! Ne gre jih zametovati, zato je še toliko bolj nerazumljivo, da krščansko usmerjeni krogi pišejo povsem neoliberalistične razvojne programe in do onemoglosti prisegajo na privatizacijo kot Velikega Mesijo in v njej vidijo že nekaj odrešenjskega, nekakšno Obljubljeno deželo. Sodobna krščanska misel (Jürgen Moltmann) pa zahteva poglobljeno utopično "vizijo prihodnosti«, ki temelji na izravnavi (Ausgleich) med svobodo in enakostjo, skratka, gre za razvito solidarnost.

Kako s čim utopičnim, s srčnostjo oporekati zdajšnji zagnanosti v privatizacijo? Vemo, da je bil utopični namen države blaginje, tj. socialna država, mišljen kot ureditev, ki naj bi "preprečevala današnji nagon privatizacije (okrajšava za pospeševanje $\mathrm{v}$ temelju protiskupnostnih, individualiziranih vzorcev delovanja potrošniškega trga, vzorcev, ki postavljajo posameznike v tekmovalne odnose z drugimi): nagon, ki se 
izraža v slabitvi in razpadu mreže človeških odnosov ter spodkopavanju družbenih temeljev človeške solidarnosti« (Zygmunt Bauman: Kolateralna škoda: družbena neenakost v globalni dobi, ZZFF, Ljubljana 2011, 17). Takó privatizacija s polnimi usti demokracije »prelaga družbeno ustvarjene probleme na ramena posameznih moških in žensk, ki tej nalogi običajno niso niti približno kos, medtem ko socialna država stremi k povezovanju svojih članov, da bi obvarovala vse in vsakogar pred krutim in moralno pogubnim spopadom vseh proti vsem« (prav tam). Zato še vedno negujemo utopijo bivanja, tj. ideal domovanja, da $\mathrm{v}$ tem kratkem življenju, ki ga živimo med rojstvom in smrtjo, bivamo povsod v svetu, kot da smo doma. V svet in razmere $\mathrm{v}$ njem vnašamo mir, torej mirimo, ne pa po privatizacijski evforiji merimo vse $\mathrm{v}$ dobičku in profitu in tako po velikoevropejsko v posojilih, ki samo naraščajo. Miru v svetu ne bo brez socialnega miru. 